\title{
Stock Repurchases: A Theoretical Prediction Model
}

Craig Santicola, Westmoreland County Community College, USA

\begin{abstract}
There has been a shift in payout policy over the last 15 years with firms opting to conduct stock repurchases over paying dividends. As repurchases have grown so has the corresponding research. Of particular note are findings that identify factors contributing to a firm's buyback decision and as well as those that support the existence of long-run return anomalies. While several notable researchers have reported the prevalence and persistence of stock repurchase anomalies, this paper examines the history of repurchase theory and presents a theoretical repurchase prediction model. Using variables shown in the literature to have influence on the decision to repurchase stock, a probit estimation model is developed as a means to identify firms likely to conduct repurchase programs.
\end{abstract}

Keywords: Payout policy; stock repurchases; repurchase theory; dividend theory; repurchase prediction model

\section{INTRODUCTION}

$\mathrm{n}$ the traditional sense, modern finance has focused on the theory of dividend policy as a method of delivering value to stockholders. So much so, that every textbook in finance includes a chapter or two on the subject. However, Brav, Graham, Harvey, and Michaely (2004) indicate that the number of firms that pay dividends has fallen, while both Fama and French (2001) and Grullon and Michaely (2002) report that the number of stock repurchases has increased. This shift in payout policy has been significant and sustaining. Grullon and Ikenberry (2000) reported that between the five year period from 1995 to 1999, companies in the U.S. announced the repurchase of close to $\$ 750$ billion worth of stock. During the same time frame, they also found, for the first time in history, more cash flows were distributed to investors by repurchases than by dividends.

As stock repurchases have grown in the U.S. so has the corresponding research. Of particular note is the finding that long-run return anomalies appear to exist. Early research by Loomis (1985) and Davidson and Garrison (1989) have shown the average returns of firms conducting repurchases to be as much as $8 \%$ above the average return on the overall market. More recently, Ikenberry, Lakonishok, and Vermaelen (1995) found that during the 1980 's the annual abnormal return for repurchase firms was $6.4 \%$ over a four year period.

Over the years there have been numerous theories as to why these firms have experienced long term return anomalies. Dittmar (2000), Maxwell and Stephens (2003) and Gelb (2000) provide evidence of a signaling theory. Ikenberry, Lakonishok, and Vermaelen (2000), D'Mello and Shroff (2000) and Chan, Ikenberry and Lee (2004), support the undervaluation theory. The free-cash theory is supported by research performed by Guay and Harford (2000) and Brav, Graham, Harvey, and Michaely (2004).

This paper presents a theoretical prediction model of repurchase factors. A test to confirm the presence of abnormal returns associated with U.S. stock repurchases using the Fama-French 3-factor model will be discussed and a prediction model of repurchase factors will be presented. Since the prediction model will be constructed of several variables from differing repurchase theories, a review of the various repurchase literature is conducted.

\section{LITERATURE REVIEW}

Many of the recent papers are concerned with the signaling theory of repurchases. Isagawa (2000) gave an 
explanation of open market stock repurchases and stock price behavior. He found that there is asymmetry of information with the private benefits managers can attain. His model showed that the repurchase announcements reveal information regarding these benefits. This differed from prior research, in that Isagawa (2000) showed that the announcements of open market repurchase programs can be believable without the restriction that the announcements are actually commitments. The model predicted that the price of a stock will fall before an open market announcement and subsequently rises once the announcement is made. In Isagawa (2002), a signaling equilibrium that does not assume that the repurchase announcement represents a commitment is established. This model assumed that repurchases are superior to dividends and that pessimistic noise exists when the interim cash flow is uncertain. However, it forecasted positive long-run stock returns and positive post open market announcement effects.

Maxwell and Stephens (2003) analyzed abnormal stock, bond and firm returns associated with repurchase announcements. Using a large sample of firms which held publicly traded debt and conducted a repurchase between 1980 and 1990, the authors found during the announcement period stocks had abnormally positive returns; bonds had negative returns and there were positive returns to the firm. The standard event study methodology was used. Also found was an insignificant correlation between stock and bond returns. The authors contend that in view of the positive returns to the firm, the data does not support the wealth transfer theory. The sample was then segmented into positive and negative signal firms. For firms with a positive signal, statistically significant positive stock and bond abnormal returns were found. There was also negative correlation between bond values and changes in stock. The negative signal firms had statistically significant positive stock and negative bond abnormal returns, along with negative correlation between changes in stock and bond values. However, one drawback to their method is that the mean adjusted model used does not correct for changes in credit spreads. On the whole, Maxwell and Stephens (2003) showed that the gain to stockholders around open market repurchase announcements was a combination of the signaling and the wealth transfer theories. The degree to which theory is more prevalent was found to depend on the signal.

Taking an accounting approach to signaling, Gelb (2000) used stock repurchases, dividends and accounting disclosures to explore the substitutability among these signals. Evidence is presented that shows, for some firms, dividends and stock repurchases may be less costly than accounting disclosures and that firms operating in industries with low barriers to entry are more prone to transmitting favorable news through dividends or repurchases as opposed to using accounting disclosures. It seemed that these firms were trying to rely on repurchases to convey good news to investors without releasing the details of the information. Using a survey of financial executives on payout policies, Brav, Graham, Harvey, and Michaely (2004) also contend that dividends and repurchases are substitutes.

Just as popular in today's research as the signaling theory, is the undervaluation approach. This is expected as it is truly a sub-sector of the signaling approach. Chan, Ikenberry and Lee (2004) used cross sectional differences in short and long run returns of firms conducting repurchases to investigate three key economic motives for repurchases; undervaluation, free cash flow, and altering leverage. The data set used consisted of over 5,000 U.S. firms that announced a repurchase between 1980 and 1996. It was found that the short-horizon reaction to repurchase announcements showed only minimal support for the mispricing theory and no evidence of the free cash flow hypothesis was identified. The long run horizon, however, showed the post repurchase drift exhibited some consistency with mispricing and to a lesser degree free cash flow.

In line with the findings of Chan, Ikenberry and Lee (2004), D'Mello and Shroff (2000) looked at equity undervaluation and decisions related to repurchase offers. Using an earning based residual income valuation model with the assumption that managers had perfect foresight, a direct test of whether firms that repurchase shares are undervalued compared to their economic value was conducted. Three relevant findings were revealed. First, 74 percent of the repurchasing firms are undervalued prior to tender compared to 51 percent of the control sample of non-repurchasing firms. The authors also found that the tender premium is highly correlated with the magnitude of undervaluation. Lastly, the decision to satisfy oversubscription demand is significantly influenced by the magnitude of undervaluation. The results were consistent even when the perfect foresight assumption is dropped. This suggests that decisions to repurchase are in line with managers possessing superior information regarding their firm's true economic value and thus, support the undervaluation theory. 
Peyer and Vermaelen (2005) studied 737 privately negotiated (greenmail) stock repurchases between the years 1984 and 2001. They found, contrary to previous research, positive announcement returns and premiums that are not significantly different from zero. Three conclusions are evident from this analysis. First, similar to other recent findings, a firm will repurchase shares from investors only when the stock is undervalued. Second, the market does not seem to recognize the undervaluation. The last finding is that target repurchase premiums are mainly determined by the bargaining power of the seller and the firm. Comparable findings on the issue of greenmail repurchases were also found by Chang and Hertzel (2004).

Differing from the results of other repurchase theories, Grullon and Michaely (2004) found that announcement of repurchase programs were not followed by an increase in performance. Still, there was a decrease in systematic risk and cost of capital in repurchasing firms as compared to non-repurchasing firms. This is consistent with the theory of free cash flow. As is the finding that in firms more likely to over-invest, the market reaction to repurchase announcements is more positive. Investors, on the other hand, were found to underestimate the cost of capital and thus, under-react to the firms' announcement.

Additional evidence of the free cash flow theory came from Guay and Harford (2000). They found that firms tend to issue repurchases from cash streams that were not of regular occurrence while dividends were distributed from cash flows that were considered permanent. As mentioned earlier, Brav, Graham, Harvey, and Michaely (2004) contend that dividends and repurchases are substitutes. However these findings also support the Guay and Hartford (2000) findings of residual/permanent cash-flow disbursements.

Grinstein and Michaely (2005) examined the relationship between institutional holdings and payout policy in U.S. public firms. To test their hypothesis, the authors used a large data set of corporate payouts and institutional holdings between 1980 and 1996. It was discovered that institutions are not generally attracted to firms that pay out more. But, of the firms that do pay out, institutions seem to prefer those that conduct repurchases on a regular basis to those that pay dividends or only repurchase sporadically. No evidence was found that firms signaled their true value by increasing dividends as a means to attract institutions. Quite conversely, as a group, it appeared that institutions reduce their holdings in firms that do increase their dividend payout while boosting the holdings in firms tending to pursue repurchases.

\section{METHODOLOGY}

\section{Fama French Time Series Test of Abnormal Returns}

The methodology to be used in this model would stem largely from the model proposed by Ikenberry, Lakonishok, and Vermaelen (2000). First, in order to test for long-term abnormal returns, the Fama-French 3-factor model would be employed to calculate monthly returns in calendar time for a portfolio of firms that conducted a repurchase. Firms would be added to the portfolio and held for the following three years. As months pass, new firms are added and firms that have reached the 3 year mark are withdrawn from the portfolio. The firms would be weighted equally and the returns calculated for year 1, year 2 and year 3.

Using a time series regression on the repurchase portfolio the model would be:

$\mathrm{R}_{\mathrm{pt}}-\mathrm{R}_{\mathrm{rf}}=\alpha+\beta_{\mathrm{pm}}\left(\mathrm{R}_{\mathrm{mt}}-\mathrm{R}_{\mathrm{ft}}\right)+\beta_{\mathrm{ps}}\left(\mathrm{SMB}_{\mathrm{t}}\right)+\beta_{\mathrm{ph}}\left(\mathrm{HML}_{\mathrm{t}}\right)+\varepsilon_{\mathrm{t}}$

where $\alpha$ is a measure for the abnormal return. SMB is defined as the difference between the returns on diversified portfolios of small and large cap stocks and HML is the difference between the returns on diversified portfolios of high and low book-to-market stocks. The term $\mathrm{R}_{\mathrm{mt}}-\mathrm{R}_{\mathrm{ft}}$ reflects the market risk premium for time period $\mathrm{t}$.

After the regression is run, the following hypothesis would be tested for statistical and economic significance via t-test:

Ho: $\quad \alpha=0$ (the abnormal returns of the portfolio are equal to zero). 
Ha: $\quad \alpha \neq 0$ (Abnormal returns are present in the sample).

This would be conducted to first identify positive abnormal returns. Once done, the prediction model can be constructed.

\section{Repurchase Prediction Model}

To begin the model, the sample of firms that conducted a repurchase would be used in conjunction with a sample of non-repurchasing firms. Due to the selection process of the repurchased firms, when combined, the samples are not purely random. To account for this Waldman (2000) recommends that the observations be weighted in the log-likelihood function. In this case, for those that repurchased, the weight would be the fraction in the population who chose to repurchase divided by the fraction in the sample that chose to repurchase.

Using variables which have been shown to have influence in a firm's decision to repurchase its stock, the theoretical probit estimation model would be:

$\underset{+\varepsilon}{\mathrm{RP}}=\beta_{0}+\beta_{1}\left(\mathrm{R}_{\mathrm{m}}-\mathrm{R}_{\mathrm{f}}\right)+\beta_{2} \mathrm{SMB}+\beta_{3} \mathrm{HML}+\beta_{4} \Delta \mathrm{CF}+\beta_{5} \mathrm{TOSO}+\beta_{6} \mathrm{IND}+\beta_{7} \Delta \mathrm{AE}+\beta_{8} \mathrm{GDPGR}+\beta_{9} \$ \mathrm{MRP}+\beta_{10} \mathrm{PRP}$

The first three variables are proxies for market conditions, size and under/over-valuation. These Fama French factors have received notable attention in the academic literature, most notably by Fama-French (1996), Dittmar (2000), and in Ikenberry, Lakonishok and Vermaelen (1995, 2000).

Jagannathan, Stephens and Weisbach (2000) and Dejong, Van Dijk, and Veld (2003) found support of the free cash flow theory. They found that firms with excess cash are likely to payout more through repurchases to reduce agency costs. The variable $\Delta \mathrm{CF}$ is defined as the percent change in total cash flows from the two most recently completed quarters as a proxy for free cash flows.

TOSO is a proxy for total outstanding stock options. It has been found by Kahle(2002) and Dejong, Van Dijk, and Veld (2003) that the presence of stock options create an incentive for firms to repurchase.

In a recent study of stock repurchases and industry affiliation, Liano, Huang and Manakyan (2003) identify significant differences in the returns across industry groups. As such, IND is a dummy variable to account for industry affiliation.

In addition to their previous findings, Chan, Ikenberry, and Lee (2004) site earnings as an important factor in a firm's decision to conduct a repurchase. $\triangle \mathrm{AE}$ represented by the percent change in annual earnings is a proxy to capture this.

The variables MRP and PRP are the dollar value of repurchases in the market for the previous quarter and a dummy variable for previous repurchases with 3 years. GDPGR is the growth rate of GDP and is included to consider overall economic conditions.

For convenience, the above model will be presented in the matrix format written as: $R_{i}=X \beta$, where $R P_{i}$ is a qualitative dummy variable with the value of 1 if the firm conducts a repurchase and a zero if not. $\beta$ is a vector of the coefficients to be estimated and $\mathrm{X}$ is the matrix of the independent variables. The error term is not present in the model, however, appears in an unobserved repurchase index of the explanatory variables, expressed as $(\mathrm{X} \beta+\varepsilon)$. In this case, a firm is viewed as having a level of utility associated with choosing a repurchase $(\mathrm{RP}=1)$. If this utility exceeds a threshold (usually normalized to zero) then the firm will repurchase. This can be seen as:

$\operatorname{Pr}\left(\mathrm{RP}_{\mathrm{i}}=1\right)=\operatorname{Pr}(\mathrm{X} \beta+\varepsilon>0)=\operatorname{Pr}(\varepsilon>-\mathrm{X} \beta)$

This is a cumulative normal distribution function from which we can compute the probability of a firm to conduct a repurchase. Estimation would be undertaken by employing maximum likelihood using the weighted $\log$ 
likelihood function discussed above. A likelihood ratio test would be performed to test:

Ho: $\quad$ All $\beta=0$ (The independent variables have no significant effect on the probability that a firm will conduct a repurchase)

Ha: $\quad$ All $\beta \neq 0$ (The independent variables have an effect on the probability of repurchase)

The estimation results of the probit equation and the LR test would be presented along with a prediction success table. It is important to note that since a probit model was estimated differences in the output data will be seen. For instance, probit models will generally return very low R2. There is no universally accepted goodness of fit measure, however, a paper by Veall and Zimmerman (1996) provides several alternative measures. Also, when looking at the variables, the marginal effect of the independent variable on the repurchase decision (1/0) is not given by the variables coefficient. In this case, the marginal effect would vary with each observation. A common practice to report the marginal effects is to report the mean values of the independent variables as a basis for inferring changes in probability.

\section{CONCLUSION}

There has been a shift in payout policy over the last 15 years with firms opting to conduct stock repurchases over paying dividends. The literature has yielded numerous theories and findings. Of particular note are findings that identify factors contributing to a firm's buyback decision and as well as those that support the existence of long-run return anomalies. While several notable researchers have reported the prevalence and persistence of stock repurchase anomalies, this paper examined the history of repurchase theory and presented a theoretical repurchase prediction model. Using variables shown in the literature to have influence on the decision to repurchase stock, a probit estimation model was developed as a means to identify firms likely to conduct repurchase programs. The results of the model, if constructed with data, would provide support for or evidence against the individual repurchase theories.

\section{AUTHOR INFORMATION}

Craig F. Santicola is currently an Assistant Professor of Economics and Business at Westmoreland County Community College. His research interests focus on market efficiency, stock repurchases and enhancing critical thinking in economics and finance instruction. Outside of academia, Craig enjoys traveling, hiking/biking, and has recently begun snowshoeing. He currently resides in Western Pennsylvania and can be reached via email at santicolac@my.wccc.edu.

\section{REFERENCES}

1. Brav, Alon, John Graham, Campbell Harvey, and Roni Michaely, 2004, Payout Policy in the $21^{\text {st }}$ Century, Journal of Financial Economics.

2. Brockman, Paul, and Dennis Chung, 2001, Managerial Timing and Corporate Liquidity: Evidence from Actual Share Repurchases, Journal of Financial Economics, 61(3), 417-448.

3. Chan, Konan, David Ikenberry, and Inmoo Lee, 2004, Economic Sources of Gain in Stock Repurchases, Journal of Financial and Quantitative Analysis, 39(3), 461-479.

4. Chan, Konan, David Ikenberry, and Inmoo Lee, 2004, Do managers Time the Market? Evidence from open market share repurchases, Working paper.

5. Chang, Saeyoung, and Michael Hertzel, 2004, Equity Ownership and Firm Value: Evidence from Targeted Stock Repurchases, The Financial Review, 39, 389-407.

6. Davidson, W.N., and S.H. Garrison, 1989, The Stock Market Reaction to Significant Tender Offer Repurchases of Stock: Size and Purpose Perspective, The Financial Review \#24, 93-107.

7. Dejong, A., R Van Dijk and C. Veld, 2003, The Dividend and Share Repurchase Policies on Canadian Firms: Empirical Evidence Based on an Alternative Research Design. International Review of Financial Analysis 12 (4), 349-377.

8. Dittmar, Amy, 2000, Why Do Firms Repurchase Stock?, Journal of Business, 73(3), 331-355. 
9. D'Mello, Ranjan, and Pervin Shroff, 2000, Equity Under-Valuation and Decisions Related to Repurchase Tender Offers: An Empirical Investigation, Journal of Finance, 60(5), 2399-2421.

10. Fama, Eugene, and Kenneth French, 1996, Multifactor Explanations of Asset Pricing Anomalies, Journal of Finance LI, 55-84.

11. Fama, Eugene, and Kenneth French, 2001, Disappearing dividends: Changing firm Characteristics or lower propensity to pay?, Journal of Financial Economics 60, 3-43.

12. Gelb, David, 2000, Corporate Signaling with Dividends, Stock Repurchases, and Accounting Disclosures: An Empirical Study, Journal of Accounting, Auditing, and Finance, 15(2), 99-120.

13. Gonzalez, Victor, and Francisco Gonzalez, 2004, Stock Repurchases with Legal Restrictions: Evidence from Spain, European Journal of Finance, 10, 526-541.

14. Grinstein, Yaniv, and Roni Michaely, 2005, Institutional Holdings and Payout Policy, Journal of Finance, 60(3), 1389-1426.

15. Grullon, Gustavo, and Roni Michaely, 2002, Divdends, Share Repurchases, and the Substitution Hypothesis, Journal of Finance 62, 1649-1684.

16. Grullon, Gustavo, and Roni Michaely, 2004, The Information Content of Share Repurchase Programs, Journal of Finance, 59(2), 651-679.

17. Grullon, Gustavo, and David Ikenberry, 2000, What do we know about stock repurchase? Journal of Applied Corporate Finance, 13, 31-51.

18. Guay, Wayne, and Jarrad Harford, 2000, The Cash-flow Permanence and Information Content of Dividend Increases versus Repurchases, Journal of Financial Economics, 57(3), 385-415.

19. Hatakeda, Takashi, and Nobuyuki Isagawa, 2004, Stock Price Behavior Surrounding Repurchase Announcements: Evidence from Japan, Pacific-Basin Finance Journal, 12(3), 271-291.

20. Ikenberry, David, Josef Lakonishok, and Theo Vermaelen, 1995, Market Under-reaction to Open Market Share Repurchases, Journal of Financial Economics, 39, 181-208.

21. Ikenberry, David, Josef Lakonishok, and Theo Vermaelen, 2000, Share Repurchase in Canada:Performance and Strategic Trading, Journal of Finance, 55, 2373-2397.

22. Isagawa, Nobuyuki, 2000, Open Market Stock Repurchases and Stock Price Behavior when Management Values Real Investment, The Financial Review, 95-108

23. Isagawa, Nobuyuki, 2002, Open Market Repurchase Announcements and Stock Price Behavior in Inefficient Markets, Financial Management, 5-20.

24. Jagannathan, M, C. Stephens and M. Weisbach, 2000, Financial Flexibility and the Choice between Dividends and Stock Repurchases, Journal of Financial Economics 57 (3), 355-384.

25. Jagannathan, Murali and Clifford Stephens, 2003, Motives for Multiple Open-Market Repurchase Programs, Financial Management, 71-91.

26. Jung, Sung-Chang, Yong-Gyo Lee, and John Thornton, 2005, An Empirical Comparison between Operations of Stabilization Funds and Stock Repurchases in Korea, Pacific-Basin Finance Journal, 13(3), 319-341.

27. Kahle, Kathleen, 2001, When a Buyback Isn't a Buyback: Open Market Repurchases and Employee Options, Journal of Financial Economics 63(2), 235-261.

28. Kennedy, Peter, 2003, “A Guide to Econometrics, Fifth Edition” MIT Press

29. Liano, K., G. Huang and H. Manakyan, 2003, Market Reaction to Open Market Stock Repurchases and Industry Affiliation, Quarterly Journal of Business and Economics 42 (1-2), 97-120.

30. Loomis, C, 1985, Beating the market by buying back stock. Fortune, (April), 42-48.

31. Maxwell, William, and Clifford Stephens, 2003, The Wealth Effects of Repurchases on Bondholders, Journal of Finance, 63(2), 895-919.

32. Peyer, Urs, and Theo Vermalen, 2005, The Many Facets of Privately Negotiated Stock Repurchases, Journal of Financial Economics, 75, 361-395.

33. Peyer, Urs, and Theo Vermaelen, 2005, The Nature and Persistence of Buyback Anomalies, INSEAD Working Paper

34. Veall, M., and K.F. Zimmermann, 1996, Pseudo-R2 Measures for some Common Limited Dependent Variable Models, Journal of Economic Surveys 10, 241-259.

35. Waldman, D.M., 2000, Estimation in Discrete Choice Models with Choice Based Samples, American Statistician 54, 303-306 